\title{
Role of sociodemographic factors and self-efficacy in the perception of social support of nursing students
}

\author{
Papel dos fatores sociodemográficos e da autoeficácia na percepção \\ de apoio social de graduandos de enfermagem \\ Rol de los factores sociodemográficos y de la autoeficacia en la percepción \\ de apoyo social de estudiantes de graduación en enfermeira
}

How to cite this article:

Ferreira RT, Gonçalves JS, Oliveira JL, Santos MVDR, Baldassarini CR, Souza J. Role of sociodemographic factors and self-efficacy in the perception of social support of nursing students. Rev Esc Enferm USP. 2021;55:e20210209. https://doi.org/10.1590/1980-220X-REEUSP-2021-0209

\section{Rafaela Teodoro Ferreira ${ }^{1}$ \\ Jamila Souza Gonçalves ${ }^{2}$ \\ Jaqueline Lemos de Oliveira ${ }^{1}$ \\ (D) Marcelo Vinicius Domingos \\ Rodrigues dos Santos ${ }^{1}$ \\ Caíque Rossi Baldassarini ${ }^{1}$ \\ D Jacqueline de Souza ${ }^{1}$}

${ }^{1}$ Universidade de São Paulo, Escola de Enfermagem de Ribeirão Preto, Programa de Enfermagem

Psiquiátrica, Ribeirão Preto, SP, Brazil.

${ }^{2}$ Instituto Federal de Educação, Ciência e Tecnologia do Sul de Minas, Passos, MG, Brazil.

\begin{abstract}
Objective: To analyze the role of sociodemographic factors and self-efficacy in the perception of social support by nursing students of the first years of nursing school. Method: This is a quantitative cross-sectional research, developed with 121 undergraduate students from the early years of the course. A sociodemographic questionnaire, the Higher Education Self-Efficacy Scale and the abbreviated version of the Social Support Questionnaire were used. Spearman and Mann-Whitney correlation tests were performed using software for statistical analysis. Results: It was identified that students with better self-efficacy and who are self-declared black or brown reported, respectively, greater satisfaction with the support and a smaller number of supporters. Conclusion: Considering that the race/color factor had a negative influence and self-efficacy a positive influence in the perception of social support, it is recommended that mental health promotion strategies be conducted that permeate both affirmative action policies and improvements in the teaching-learning process, especially in the first years of the nursing course.
\end{abstract}

\section{DESCRIPTORS}

Self Efficacy; Social Support; Students; Nursing; Mental Health; Health Promotion.
Corresponding author:

Jaqueline Lemos de Oliveira

Avenida dos Bandeirantes, 3900, Monte Alegre

14040-902 - Ribeirão Preto, SP, Brazil

jaquelemos@usp.br
Received: 05/04/2021

Approved: 07/26/2021 


\section{INTRODUCTION}

Higher education entry is marked by numerous affective, cognitive, and social challenges, but it is also an important provider of useful experiences, both for personal development and for professional training ${ }^{(1-2)}$.

Passing the entrance exam, especially in public universities, represents an important achievement; however, it is also inevitable that freshmen face difficulties in dealing with situations such as moving to another city to attend the chosen college, homesickness, autonomy and responsibility when dealing with finances, adaptation to the new environment, the new people, and the new routine and way of studying, which will require greater dedication and more independent decision-making ${ }^{(1-2)}$.

Despite the general challenges, this transition is unique for each student and the development of healthy coping mechanisms is of paramount importance. In this regard, social support and self-efficacy have been described as facilitators of the adaptation process of individuals during transition periods, as they promote improvements in mental health and increase the sense of safety and well-being, besides favoring processes of resilience ${ }^{(2-4)}$.

Student support networks are of great importance for the management of stressful situations, both in the transition period and in academic adaptation, and the lack of supporters can contribute to worse time management and less planning and organization of studies, involving issues related to autonomy, self-regulation, academic motivation, and success at the end of the first year ${ }^{(5-7)}$.

Several studies with students, nationally and internationally, have considered the role of both social support and self-efficacy in well-being ${ }^{(4)}$, in the adoption of healthy lifestyle habits ${ }^{(5-6)}$, in coping with negative situations ${ }^{(8)}$, academic performance ${ }^{(9-10)}$, in physical ${ }^{(11)}$ and mental health ${ }^{(3)}$, with some of these studies being developed with students of primary education or high school ${ }^{(5-6,8)}$. Among the recent studies that are based on this idea of synergy between social support and self-efficacy and that were developed with university students ${ }^{(3-4,9-11)}$, some considered several courses together ${ }^{(4,9)}$ or students from courses other than nursing ${ }^{(3,10-11)}$.

Thus, the need to increase studies on this topic, specifically involving nursing students, is an important aspect, given the particular stressors of this course, namely, the curriculum that includes theoretical activities, laboratory practices, and immersion in the practice scenario, performance of care actions to different populations, constant evaluation, continuous contact with human suffering, and the still culturally low prestige of the occupation ${ }^{(1,8)}$.

Another specificity to be considered is related to the characteristics of the first-year students in the course, as researchers have emphasized the period of adaptation to the environment, curriculum structure, schedule, and the nuances of health work as important challenges in the early years of the course ${ }^{(12-13)}$.

Furthermore, these studies on the phenomenon in question have focused on the synergy of self-efficacy constructs as an internal resource and social support as an external resource, without necessarily contextualizing such resources in relation to cultural background (such as ethnicity) or other sociodemographic aspects (such as the students' gender and age group).

Given this gap, this study aims to analyze the role of sociodemographic factors and self-efficacy in the perception of social support by nursing students of the first years of nursing school.

\section{METHOD}

\section{Design and Local of Study}

This is a cross-sectional quantitative study, carried out on a campus of a public university in an inland city of the state of São Paulo, Brazil.

\section{Population, Selection Criteria and Sample}

The study population consisted of students from the first and second years of the undergraduate nursing course at that institution. Eligibility criteria were: students enrolled in the initial years of the undergraduate nursing course and who were over 18 years. The invitation to participate in the study was made in person in the classrooms, through a written invitation given to students during classes breaks.

During the period of the study, the total number of nursing students was 591; of these, 240 students made up the listed population. All students of this population were invited to participate in the study $(\mathrm{N}=240), 8 \%$ of them were under 18 years of age and $54.8 \%$ of those eligible accepted the invitation. Regarding refusals, the alleged reason was lack of time or participation in another research in the same period. Thus, the final sample consisted of 121 students.

\section{Data Collection}

Data collection was carried out from April to June 2019 by three nursing students (two undergraduates and one doctoral student) previously trained for this purpose. The self-reported questionnaires were distributed among the students in the sample $(\mathrm{n}=121)$ along with the Free Informed Consent Form. All students returned the completed questionnaires.

Information on the sociodemographic profile, social support, and self-efficacy was collected through the instruments: sociodemographic questionnaire, the short version of the Social Support Questionnaire (SSQ6) ${ }^{(14)}$ and the Higher Education Self-Efficacy Scale (AEFS) ${ }^{(15)}$.

The sociodemographic data questionnaire was designed by the researchers considering the minimum indicators described by the Brazilian Institute of Geography and Statistics ${ }^{(16)}$ and contained information on participants' sex, age and color.

The SSQ6 consists of six questions analyzing the number of people who make up the individual's social network (SSQN score) and the degree of satisfaction with the perceived social support (SSQS score) $)^{(14)}$. The individual shall list up to nine people per question, and may also answer "no one", and rate their satisfaction with the support in each 
situation listed in the questions based on a six-point Likert scale, in which six corresponds to "very satisfied" and one to "very dissatisfied". This instrument has high values of internal consistency, assessed by Cronbach's alpha, which ranged from 0.90 for the SSQN and 0.93 for the SSQS, and has been validated for use in Brazil ${ }^{(14)}$.

The AEFS, developed and validated in Brazil, contains 34 items related to the trust perceived by the participant in five dimensions: academic, training regulation, social interaction, proactive actions, and academic management ${ }^{(15)}$. Cronbach's alpha obtained in the different dimensions were, respectively, $0.88,0.87,0.80,0.85$, and 0.80 .

Each item has as an answer option a Likert scale from 0 to 10 . The calculation of the average of the items corresponding to each dimension composes the scores per dimension. The overall score was obtained from the score average of the different dimensions, with a mean value of 5.5. That is, means below this value would indicate weak self-efficacy beliefs; between 5.5 and 6, fragile beliefs; and means above 7 would suggest strong beliefs ${ }^{(15)}$. Appropriate authorizations were obtained for the use of the scales by the research group.

\section{Data Analysis and Treatment}

The data obtained were tabulated in an Excel for Windows spreadsheet and double-entered by the researchers involved, to validate and obtain reliable and error-free data. Following this first step, the spreadsheet was taken to a definitive database in the IBM ${ }^{\circledR}$ SPSS software, version 23.0, in which the analyses were conducted.

At first, the characterization of the participants' profile was carried out, with the description of the sociodemographic data of the study population, using descriptive statistics, such as simple frequency, measures of central tendency (mean and median) and measures of variability or dispersion (standard deviation, minimum and maximum).

Subsequently, the normality test was performed to obtain the distribution of the scores of the instruments used. Since the distribution of the analyzed variables was not normal, non-parametric tests were used, namely: Spearman's correlation, considering the social support scores (number and satisfaction) and the global scores and the different dimensions of the self-efficacy scale; and Mann-Whitney test for social support scores (number and satisfaction), age (dichotomized in up to 20 years and more than 20 years), color (dichotomized in white/yellow and black/brown) and sex (male or female). An alpha of 0.05 was adopted.

\section{Ethical Aspects}

The project was submitted to the Research Ethics Committee of the Nursing School of Ribeirão Preto of the Universidade de São Paulo and was approved by Opinion No. 20 of February 06, 2019. The research development followed the guidelines and regulatory standards for research involving human beings, as established by Resolution No. 466/2012 of the National Health Council.
Table 1 - Difference among social support scores according to the participants' sociodemographic characteristics - Ribeirão Preto, SP, Brazil, $2019(n=121)$.

\begin{tabular}{|c|c|c|c|c|c|}
\hline \multirow[t]{2}{*}{ Variables } & \multirow[t]{2}{*}{ n (\%) } & \multicolumn{2}{|c|}{$\begin{array}{c}\text { Score of } \\
\text { satisfaction with } \\
\text { social support }\end{array}$} & \multicolumn{2}{|c|}{$\begin{array}{l}\text { Score of number } \\
\text { of supporters }\end{array}$} \\
\hline & & $\begin{array}{l}\text { Rank } \\
\text { mean }\end{array}$ & $\mathbf{p}^{*}$ & $\begin{array}{l}\text { Rank } \\
\text { mean }\end{array}$ & $\mathbf{p}^{*}$ \\
\hline \multicolumn{6}{|l|}{ Sex } \\
\hline Female & $103(85.1)$ & 61.99 & \multirow{2}{*}{0.443} & 63.37 & \multirow{2}{*}{0.073} \\
\hline Male & 18(14.9) & 55.36 & & 47.42 & \\
\hline \multicolumn{6}{|l|}{ Age range } \\
\hline Up to 20 years & $79(65.8)$ & 60.69 & \multirow[b]{2}{*}{0.931} & 60.85 & \multirow[b]{2}{*}{0.878} \\
\hline $\begin{array}{l}\text { More than } \\
20 \text { years }\end{array}$ & $41(34.2)$ & 60.14 & & 59.83 & \\
\hline \multicolumn{6}{|l|}{ Color $^{\dagger}$} \\
\hline White/Yellow & $93(76.9)$ & 62.04 & \multirow{2}{*}{0.536} & 64.51 & \multirow{2}{*}{0.043} \\
\hline Black/Brown & 28(23.1) & 57.54 & & 49.34 & \\
\hline
\end{tabular}

* Mann-Whitney test; ${ }^{+}$White/Yellow Students - average number of supporters referred to 6.28; minimum 2; maximum 13; Black/Brown - average number of supporters referred to 5.21 ; minimum 1 ; maximum 9 .

\section{RESULTS}

As for the sociodemographic characteristics of the 121 study participants, there was a predominance of women; age ranged from 18 to 28 years, with a mean of 20.1 years $(\mathrm{sd}=2.30) ; 76.9 \%$ self-declared being white and, regarding financial dependence, $95 \%(n=115)$ depended on their parents to stay on the course.

Students showed an average of 6.03 supporters $(\mathrm{sd}=2.41)$ and an average score of satisfaction with support of 5.21 (sd = 1.12). The number of supporters was statistically different only in relation to color, that is, students who self-declared being black or brown had fewer supporters (Table 1).

Regarding self-efficacy, the mean global score was 8.14 $(\mathrm{sd}=1.30)$ and minimum and maximum values, respectively, 3 and 10. The specific mean scores for each dimension are shown in Figure 1.

Self-efficacy, in all dimensions evaluated, was positively correlated with satisfaction with social support (Table 2), with emphasis on the academic dimension (perceived confidence in the ability to learn, demonstrate, and apply the course content). Despite this, there was no correlation between self-efficacy and the number of supporters (Table 3).

\section{DISCUSSION}

Despite some authors pointing out that the interpersonal relationships that make up a social network tend to be homogeneous in several aspects such as sex, age, education, religion, and ethnicity ${ }^{(17-18)}$, in the group studied, only the participants' ethnicity showed to be relevant in relation to the perception of social support.

Considering that the number of black/brown students in public universities is still small, this result may reflect the finding of a previous study developed with medical students, 


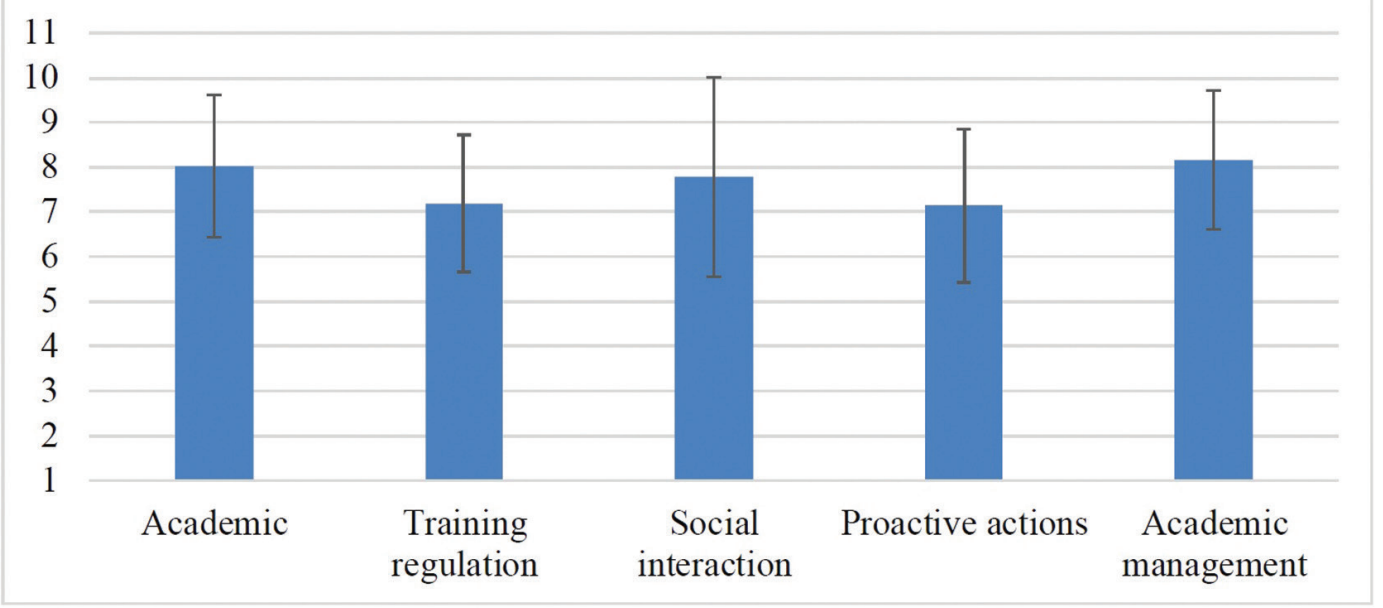

Figure 1 - Mean and standard deviation of the score of the dimensions of the self-efficacy scale - Ribeirão Preto, SP, Brazil, 2019 $(n=121)$.

Table 2 - Correlation between the social support satisfaction score and the dimensions of the self-efficacy scale - Ribeirão Preto, SP, Brazil, $2019(n=121)$.

\begin{tabular}{|c|c|c|c|c|c|c|c|}
\hline & $\begin{array}{c}\text { Score of } \\
\text { satisfaction } \\
\text { with social } \\
\text { support }\end{array}$ & $\begin{array}{l}\text { Academic } \\
\text { dimension }\end{array}$ & $\begin{array}{l}\text { Training } \\
\text { regulation } \\
\text { dimension }\end{array}$ & $\begin{array}{l}\text { Social interaction } \\
\text { dimension }\end{array}$ & $\begin{array}{l}\text { Proactive actions } \\
\text { dimension }\end{array}$ & $\begin{array}{c}\text { Academic } \\
\text { management } \\
\text { dimension }\end{array}$ & AEFS score* \\
\hline $\begin{array}{l}\text { Score of satisfaction with } \\
\text { social support }\end{array}$ & 1.000 & & & & & & \\
\hline Academic dimension & $0.337^{+}$ & 1.000 & & & & & \\
\hline $\begin{array}{l}\text { Training regulation } \\
\text { dimension }\end{array}$ & $0.205^{\ddagger}$ & $0.543^{+}$ & 1.000 & & & & \\
\hline $\begin{array}{l}\text { Social interaction } \\
\text { dimension }\end{array}$ & $0.301^{+}$ & $0.663^{+}$ & $0.671^{+}$ & 1.000 & & & \\
\hline $\begin{array}{l}\text { Proactive actions } \\
\text { dimension }\end{array}$ & $0.229^{\ddagger}$ & $0.541^{+}$ & $0.573^{+}$ & $0.576^{+}$ & 1.000 & & \\
\hline $\begin{array}{l}\text { Academic management } \\
\text { dimension }\end{array}$ & $0.257^{+}$ & $0.558^{+}$ & $0.521^{+}$ & $0.595^{+}$ & $0.504^{+}$ & 1.000 & \\
\hline AEFS score* & $0.295^{+}$ & $0.811^{+}$ & $0.814^{+}$ & $0.795^{+}$ & $0.696^{+}$ & $0.637^{+}$ & 1.000 \\
\hline
\end{tabular}

Spearman's correlation; $*$ AEFS $=$ Higher Education Self-Efficacy Scale; ${ }^{+}$Correlation is significant at the 0.01 level (two-tailed); ${ }^{*}$ Correlation is significant at the 0.05 level (two-tailed).

Table 3 - Correlation between the number of supporters and the dimensions of the self-efficacy scale - Ribeirão Preto, SP, Brazil, 2019 $(n=121)$.

\begin{tabular}{|c|c|c|c|c|c|c|c|}
\hline & $\begin{array}{c}\text { Score of } \\
\text { number of } \\
\text { nupporters }\end{array}$ & $\begin{array}{l}\text { Academic } \\
\text { dimension }\end{array}$ & $\begin{array}{l}\text { Training } \\
\text { regulation } \\
\text { dimension }\end{array}$ & $\begin{array}{c}\text { Social } \\
\text { interaction } \\
\text { dimension }\end{array}$ & $\begin{array}{l}\text { Proactive } \\
\text { actions } \\
\text { dimension }\end{array}$ & $\begin{array}{c}\text { Academic } \\
\text { management } \\
\text { dimension }\end{array}$ & AEFS score* \\
\hline Score of number of supporters & 1.000 & & & & & & \\
\hline Academic dimension & -0.004 & 1.000 & & & & & \\
\hline Training regulation dimension & -0.165 & $0.543^{+}$ & 1.000 & & & & \\
\hline Social interaction dimension & -0.017 & $0.663^{+}$ & $0.671^{+}$ & 1.000 & & & \\
\hline Proactive actions dimension & -0.050 & $0.541^{+}$ & $0.573^{+}$ & $0.576^{+}$ & 1.000 & & \\
\hline $\begin{array}{l}\text { Academic management } \\
\text { dimension }\end{array}$ & 0.021 & $0.558^{+}$ & $0.521^{+}$ & $0.595^{+}$ & $0.504^{+}$ & 1.000 & \\
\hline AEFS score* & -0.106 & $0.811^{+}$ & $0.814^{+}$ & $0.795^{+}$ & $0.696^{+}$ & $0.637^{+}$ & 1.000 \\
\hline
\end{tabular}

Spearman's correlation; * AEFS = Higher Education Self-Efficacy Scale; ${ }^{\dagger}$ Correlation is significant at the 0.01 level (two-tailed). 
in which the authors identified a tendency to "homophily" in the constitution of the participants' support network, that is, they often named people of their own ethnicity as part of their support network ${ }^{(17)}$.

The black students' interpersonal relationships were also indicated, in a previous study, as source of stress, as they felt underrepresented in relation to their specificities, an also because of the low sensitivity on the part of employees and teachers regarding sociocultural differences related to the question of race/color ${ }^{(18)}$.

Thus, it should be noted that, in the sample studied, only $23.1 \%$ of the participants self-declared being black/ brown and, even considering the fact that we had a convenience sampling, a reflection about the insertion of this group in the university is urgently required, as it is still well behind the representation of this population, since $34.5 \%$ of São Paulo residents are black ${ }^{(19)}$. These data support the premise that affirmative action policies related to admission to public universities, as well as student permanence policies with prioritization of this group, would certainly provide the strengthening of black students' identity, contributing to peer recognition and, consequently, for the possible expansion of their support networks.

Such policies are legitimized by the recognition of structural racism as a determining factor permeating these students' life history. Structural racism results from the normal functioning of society and is constituted in political, economic, legal, and family relationships ${ }^{(20)}$. Thus, it is important to evaluate how racial violence, a consequence of this racist social structure, can be reflected in the establishment of interpersonal relationships that can also be perceived as a source of social support ${ }^{(21)}$.

In addition, considering that most participants were women, this discussion shall include the issue of intersectionality, which specifically concerns the way in which racism, patriarchy, class oppression, and other discriminatory systems create basic inequalities, structuring social positions ${ }^{(22)}$. This fact is evidenced when these systems place black and brown students in a difficult situation, forged by race and gender, of lack of social support.

Given the above, one can understand that this result may reflect the scarcity of support networks for black and brown students, evidencing an important psychosocial need to be considered at the university level, which can unfold in negative experiences of this group throughout its academic pathway, and even reflect in fewer opportunities after they finish the course, based on the results pointing to the importance of support networks also for insertion in the labor market ${ }^{(23-24)}$. Thus, this important finding highlights the relevance of further research on how support networks specifically for black and brown students are formed, as well as the proposal of mental health promotion strategies that sensitively address the specificities of this group.

In contrast, when considering the total sample, it was identified that most students were satisfied with their support networks and, in this regard, there was no difference among the participants according to the analyzed sociodemographic characteristics. The fact that the variable "satisfaction with support", although being part of the same construct, is different from "number of supporters", was considered controversial, given that the number of supporters is described by classical researchers on this topic as an important predictor of satisfaction with support ${ }^{(14,25)}$. Some recent studies with other populations reinforce this evidence, pointing out that networks with more supporters increase the chances of the individual having more confident, interested, and less directive people ${ }^{(26-27)}$ to count on. Nonetheless, there are also results in recent literature that are similar to those of the present study, which have suggested that satisfaction with support assumes greater relevance as an analysis variable in studies on quality of life and health ${ }^{(8,28)}$.

Therefore, future studies are recommended that make an in-depth identification of current support satisfaction predictors, considering specific groups, especially with black or brown nursing students who, in the case of the present study, stood out in terms of reduced number of supporters. In addition, it is recommended that investigations on the subject also consider other characteristics that possibly act as mediators or moderators of the variables adopted in this study, in view of the numerous evidences on the importance of mediation and moderation relationships in processes related to provision and perception of social support $\mathrm{s}^{(7,29-30)}$.

As for self-efficacy, most students had average scores above eight, indicating strong beliefs about their abilities to deal with everyday demands, corroborating the findings of other studies that identified a good perception of selfefficacy in the population of university students in general $^{(1,2)}$. It is understood that this is an important indicator of the psychosocial health of nursing students in the new context of life, as self-efficacy is one of the dimensions that make up the psychological resources for coping and problem solving ${ }^{(1,2)}$.

The results of this study also showed a positive correlation between satisfaction with social support and the dimensions of self-efficacy, especially the academic one. That is, the greater the students' self-efficacy, the greater their satisfaction with social support. A study developed with medical students analyzing these variables ${ }^{(3)}$ did not present results on the correlation among them, emphasizing the need for future studies that undertake such analyses to contribute to a more robust body of evidence.

Regarding the particularity of the population in this study, first-year nursing students, it should be noted that the candidate/vacancy ratio in courses of the health area tends to be higher than in other areas, such as humanities and sciences; therefore, the low percentage of black or brown students in the studied sample may, in a way, reflect the issue of access specifically to this undergraduate course. In contrast, considering the specific stressors of this course, this phase of the course, and even of this profession, it is understood that students have overcome the challenges at the expense of the resources they have to face them, denoting nuances of a resilient profile for this phase of the life cycle. However, it can be observed that nursing students could benefit even more from a more qualified support network, given its consequences in self-efficacy, as well as its protective role in mental health and in the coping with adversities ${ }^{(5-7,9-11)}$. 
Important contributions to practice shall be taken from this study, especially with regard to possible institutional strategies aimed at improving supportive relationships in the academic context.

The findings point to the need to know the profile and characterization of students, both in relation to sociodemographic factors and psychosocial factors (self-efficacy, social support network, among others), as university students have particularities and specific stressors related to the undergraduate studies context. Mental health promotion strategies for such students shall be sensitive to such factors.

The limitations of the study refer to data collection in a single institution and the sample size resulting from the large number of refusals. For future studies, the development of research with designs allowing the comparison of students from different stages of the nursing course is suggested, so that more accurate evidence on the specificities of these subgroups is provided. We also suggest the inclusion of a qualitative step that could investigate the feelings and perceptions of black nursing students about their support networks and psychosocial health in academic contexts.

\section{CONCLUSION}

The present study started from the proposition that selfefficacy, color, sex, and age would play a relevant role in the perception of social support in a sample of students from the early years of undergraduate course in nursing. It was identified that higher self-efficacy and the question of race-color assumed a relevant role regarding the perception of social support of the group studied. That is, students with better self-efficacy and self-declared black/brown reported, respectively, greater satisfaction with the support and less supporters. It appears that proposals focused on improving the social support of the students in question shall permeate both affirmative policies and actions promoting the increase in the ability to learn, demonstrate, and apply what was learned in the course.

\section{RESUMO}

Objetivo: Analisar o papel dos fatores sociodemográficos e da autoeficácia na percepção de apoio social de estudantes dos anos iniciais da graduação em enfermagem. Método: Pesquisa transversal quantitativa, desenvolvida com 121 graduandos dos anos iniciais. Utilizouse questionário sociodemográfico, a Escala de Autoeficácia no Ensino Superior e a versão abreviada do Questionário de Suporte Social. Foram empreendidos os testes de Correlação de Spearman e de Mann-Whitney por meio de software para análise estatística. Resultados: Identificou-se que os estudantes com melhor autoeficácia e que se autodeclararam pretos ou pardos referiram, respectivamente, maior satisfação com o apoio e menor número de apoiadores. Conclusão: Considerando que o fator raça/cor influenciou negativamente e a autoeficácia positivamente a percepção de apoio social, recomenda-se que sejam conduzidas estratégias de promoção da saúde mental que perpassem tanto as políticas afirmativas quanto melhorias do processo de ensino-aprendizagem, sobretudo nos primeiros anos do curso de enfermagem.

\section{DESCRITORES}

Auto eficácia; Apoio social; Estudantes; Enfermagem; Saúde Mental; Promoção da Saúde.

\section{RESUMEN}

Objetivo: Analizar el rol de los factores sociodemográficos y de la autoeficacia en la percepción de apoyo social de estudiantes de años iniciales de la graduación en enfermería. Método: Investigación transversal cuantitativa, desarrollada con 121 estudiantes de graduación de los años iniciales. Se utilizó encuesta sociodemográfica, la Escala de Autoeficacia en la Enseñanza Superior y la versión sucinta de la Encuesta de Soporte Social. Fueron emprendidos los testes de Correlación de Spearman y de Mann-Whitney a través de software para análisis estadístico. Resultados: Se identificó que los estudiantes con mejor autoeficacia y que se auto declararon negros o pardos relataron, respectivamente, mayor satisfacción con el apoyo y menor número de apoyadores. Conclusión: Teniendo en cuenta que el factor etnia/color influyó de forma negativa y la autoeficacia de forma positiva la percepción de apoyo social, se recomienda que sean conducidas estrategias de promoción de la salud mental que aporten tanto las políticas afirmativas como mejorías del proceso de enseñanza-aprendizaje, sobre todo en los primeros años del curso de enfermería.

\section{DESCRIPTORES}

Auto eficacia; Apoyo Social; Estudiantes; Enfermería; Salud Mental; Promoción de la Salud.

\section{REFERENCES}

1. Ribeiro RM, Bragiola JVB, Eid LP, Pompeo DA. Impact of self-esteem and of the sociodemographic factors on the self-efficacy of udergraduate nursing students. Texto Contexto Enferm. 2020;29:e20180429. DOI: http://dx.doi.org/10.1590/1980-265x-tce-2018-0429.

2. Sanner-Stiehr E. Responding to disruptive behaviors in nursing: A longitudinal, quasi-experimental investigation of training for nursing students. Nurse Educ Today. 2018;68:105-11. DOI: http://dx.doi.org/10.1016/j.nedt.2018.05.029.

3. Hakimi S, Talepasand S. The structural relations of self-efficacy and social support with subjective well-being in medical students: mediator role of emotional exhaustion and academic engagement. Medical Education and Development Spring [Internet] 2018 [cited 2020 Apr 10];13(1):43-58. Available from: https:/www.sid.ir/en/journal/ViewPaper.aspx?ID=612437.

4. Matias RC, Martinelli SC. Um estudo correlacional entre apoio social e autoconceito de estudantes universitários. Avaliação (Campinas). 2017;22(1):15-33. DOI: https://doi.org/10.1590/s1414-40772017000100002.

5. Campos JG, Bacil EDA, Piola TS, Silva MP, Pacífico AB, Campos W. Social support, self-efficacy and level of physical activity of students aged 13-15 years. Rev bras cineantropom desempenho hum. 2019;21:e58684. DOI: https://doi.org/10.1590/1980-0037.2019v21e58684.

6. Hamilton K, Warner LM, Schwarzer R. The Role of Self-Efficacy and Friend Support on Adolescent Vigorous Physical Activity. Health Educ Behav. 2016;44(1):175-81. DOI: https://doi.org/10.1177/1090198116648266. 
7. Araújo AM, Santos AA, Noronha AP, Zanon C, Ferreira JA, Casanova JR, et al. Anticipated adaptation difficulties to higher education: a study with first-year students. Revista de Estudios e Investigación en Psicología y Educación. 2016;3(2):102-11. DOI: http://dx.doi. org/10.17979/reipe.2016.3.2.1846.

8. Almeida LY, Carrer MO, Souza J, Pillon SC. Evaluation of social support and stress in nursing students. Rev Esc Enferm USP. 2018;52:e03405. DOI: http://dx.doi.org/10.1590/S1980-220X2017045703405.

9. Liu YC, Yun YH. Self-efficacy as the moderator: Exploring driving factors of perceived social support for mainland Chinese students in Taiwan. Comput Human Behav. 2016;64:455-62. DOI: https://doi.org/10.1016/j.chb.2016.07.018.

10. Pereira CM, Souza GM, Costa NVM, Rossini RP, Gomes AM, Batista EC. Autoeficácia percebida por estudantes do primeiro período de um curso de pedagogia. Revista Científica FAEST. 2018;6(1):13-23.

11. Jackson ES, Tucker CM, Herman KC. Health value, perceived social support, and health self-efficacy as factors in a health-promoting lifestyle. J Am Coll Health. 2007;56(1):69-74. DOI: https://doi.org/10.3200/JACH.56.1.69-74.

12. Aini N. Identifying the Sources of Academic Stress and Coping Strategies in New Nursing Students. Advances in Health Sciences Research (AHSR). 2017;2:73-81. DOI: https://doi.org/10.2991/hsic-17.2017.11.

13. Alsaqri SH. Stressors and coping strategies of the Saudi nursing students in the clinical training: a cross-sectional study. Education Research International [Internet]. 2017 [cited 2021 May 01];1-9. Available from: https://www.hindawi.com/journals/edri/2017/4018470/.

14. Sarason IG, Sarason BR, Shearin EN, Pierce GR. A brief measure of social support: Practical and theoretical implications. J Soc Pers Relat. 1987;4:497-510. DOI: https://doi.org/10.1177/0265407587044007.

15. Polydoro SAJ, Guerreiro-Casanova DC. Higher education self-efficacy scale: Construction and validation research. Aval. Psicol [Internet]. 2010 [cited 2019 Oct 03];9(2):267-78. Available from: http://pepsic.bvsalud.org/scielo.php?script=sci_arttext\&pid= S1677-04712010000200011.

16. Instituto Brasileiro de Geografia e Estatística. Pesquisa Nacional por Amostra de Domicílios: síntese de indicadores. Rio de Janeiro: IBGE; 2016.

17. Vaughan S, Sanders T, Crossley N, O'Neill P, Wass V. Bridging the gap: the roles of social capital and ethnicity in medical student achievement. Med Educ. 2015;49:114-23. DOI: https://doi.org/doi:10.1111/medu.12597.

18. Morrison N, Machado M, Blackburn C. Student perspectives on barriers to performance for black and minority ethnic graduate-entry medical students: a qualitative study in a West Midlands medical school. BMJ Open. 2019;9:e032493. DOI: https://doi.org/10.1136/ bmjopen-2019-032493.

19. Brasil. Instituto Brasileiro de Geografia e Estatística (IBGE). Censo Demográfico 2010: população residente, por raça cor, segundo situação de domicilio, o sexo e a idade. In: Brasil. Instituto Brasileiro de Geografia e Estatística (IBGE). Sidra: sistema IBGE de recuperação automática. [Internet]. 2010 [cited 2020 May 26]. Available from: https://sidra.ibge.gov.br/Tabela/3175\#resultado.

20. Almeida SL. O que é racismo estrutural? Belo Horizonte: Letramento; 2018.

21. Fanon F. Pele negra, máscaras brancas. Salvador: EdUFBa; 2008.

22. Crenshaw K. Background paper for the expert meeting on the gender-related aspects of race discrimination. Rev Estud Fem. 2002;10(1): 171-88. DOI: http://dx.doi.org/10.1590/S0104-026X2002000100011.

23. Choi HJ, Jung KI. Moderating Effects of Career Decision-making Self-efficacy and Social Support in the relationship between Career Barriers and Job-seeking Stress among Nursing Students Preparing for Employment. J Korean Acad Fundam Nurs. 2018;24(1):61-72. DOI:https:// doi.org/10.11111/JKANA.2018.24.1.61.

24. Hou C, Wu Y, Liu Z. Career decision-making self-efficacy mediates the effect of social support on career adaptability: A longitudinal study. Social Behavior and Personality: an international journal. 2019;47(5):1-13. DOI: https://doi.org/10.2224/sbp.8157.

25. Stokes JP, Wilson DG. The Inventory of Socially Supportive Behaviors: dimensionality, prediction, and gender differences. Am J Community Psychol [Internet]. 1984 [cited 2021 June 30];12:53-69. Available from: https://link.springer.com/content/pdf/10.1007/BF00896928.pdf.

26. Mc Cullagh C, Quinn K, Voisin DR, Schneider J. A longitudinal examination of factors associated with social support satisfaction among HIV-positive young Black men who have sex with men. AIDS Care. 2017;29(12):1598-604. DOI: https://doi.org/10.1080/09540121.20 17.1332333.

27. Geller J, Iyar M, Srikameswaran S, Zelichowska J, Dunn EC. Social support satisfaction in adults with eating disorders: Does stance matter? Int J Eat Disord. 2017;50:842-6. DOI: http://dx.doi.org/10.1002/eat.22695.

28. Winefield HR, Delfabbro PH, Winefield AH, Plueckhahn T, Malvaso CG. Adolescent predictors of satisfaction with social support six years later: an Australian longitudinal study. J Adolesc. 2015;44:70-6. DOI: http://dx.doi.org/10.1016/j.adolescence.2015.07.004.

29. Beekman JB, Stock ML, Howe GW. Stomaching rejection: Self-compassion and self-esteem moderate the impact of daily social rejection on restrictive eating behaviours among college women. Psychol Health. 2017;32(11):1348-70. DOI: http://dx.doi.org/10.1080/0887044 6.2017 .1324972 .

30. Wu ZH, Tennen H, Hosain GMM, Coman E, Cullum J, Berenson AB. Stress Mediates the Relationship Between Past Drug Addiction and Current Risky Sexual Behaviour Among Low-income Women. Stress and Health. 2016;32:138-44. DOI: https://doi.org/10.1002/smi.2587.

\section{Financial support}

Conselho Nacional de Desenvolvimento Científico e Tecnológico - CNPq [422244/2018-0] and

Coordenação de Aperfeiçoamento de Pessoal de Nível Superior - Financing Code 001. 